\title{
Survey of sickle-cell disease in England and Wales
}

\author{
L R DAVIS, E R HUEHNS, J M WHITE
}

\begin{abstract}
The incidence and the clinical course of patients suffering from sickle-cell syndrome (Hb SS; Hb SC; $\mathrm{Hb} S$ thal) in England and Wales are not known. In 1979 an ad hoc committee was formed to investigate these problems. Initially, a questionnaire was sent to 227 haematologists in England and Wales to determine the number of cases in these countries. The replies have indicated that 1367 cases were seen in 1978 and 1979. Probably this may represent only half the total number of cases. From this survey it has been possible to draw up a composite map showing the location of patients, which has provided a basis to determine the clinical course of the disease, and for further studies into the complications and management of sickle-cell disease in England and Wales. From a second questionnaire preliminary data about the general management and mortality in England and Wales have been recorded.
\end{abstract}

\section{Introduction}

Sickle-cell disease is defined as a clinical abnormality due to the presence of only $\mathrm{Hb} \mathrm{S}$ within the red cell or $\mathrm{Hb} S$ and another haemoglobin-for example, $\mathrm{Hb} \mathrm{C}$ or $\mathrm{Hb} \mathrm{D}$-or with B-thalassaemia. With the growth of the immigrant population from the West Indies into Britain since the 1950s, sickle-cell

King's College Hospital, London SE5 9RS

L R DAVIS, MD, FRCPATH, consultant haematologist

University College Hospital Medical School, London WC1E 6JJ E R HUEHNS, MD, MRCPATH, professor of haematology

King's College Hospital Medical School, London SE5 8RX J M WHITE, MD, MRCPATH, professor of hacmatology disease has become endemic. Also, the number of cases has been supplemented over the past 20 years by immigrants from Africa who may or may not form part of the permanent population. Because of the many clinical manifestations of sickle-cell disease, affected patients will be seen by clinicians in any specialty of medicine. The morbidity and mortality of sickle-cell disease would appear to vary in different countries, depending on climate, social and economic factors, endemic disease such as malaria, and the availability of medical attention. The clinical course in Britain, however, is unknown and, also, the management of complications is based on studies reported from other countries. Only two surveys ${ }^{12}$ have been carried out in Britain, and both have been confined to a local population. No general survey has been carried out. Since it was apparent that sickle-cell disease was endemic in Britain, an ad hoc UK Sickle Cell Committee* was formed in 1979 and has investigated the following: (1) the number of patients suffering from the disease, (2) the location of sufferers, and (3) the management of patients, their complications, and mortality.

These points, once established, then provided a basis for determining the natural history in England and Wales for managing the acute complications-for instance, crises (infarctive, haemolytic, splenic sequestration, and aplastic)-and also the management of other problems-for instance, pregnancy, cold surgery, acute surgery, renal transplantation, etc.

\section{Collection of data}

A questionnaire sent to 227 haematologists in England and Wales requested the number of cases of sickle-cell disease that had been seen during the previous year and how these were distributed among

*Members of the UK Sickle-cell Committee are as follows: (London) Professor E R Huchns, chairman, Professor J M White, secretary, Dr M Brozovic, Dr J Chessells, Dr L R Davis, Dr C Dulake, Dr G Marsh, Dr L Murtaza, Professor J Pattison, Dr T Pearson, Dr J D Reeve, Dr D Rogers, Professor C E Stroud, Mr J Studd, Dr S Tuck, Dr R A Wall, Professor G Wetherley-Mein; (Cambridge) Professor H Lehmann; (Birmingham) Professor J Stuart, Dr J Mann; and (Oxford) Professor D J Weatherall. 
sickle-cell anaemia (SS), haemoglobin SC disease (SC), haemoglobin $S \beta$-thalassaemia ( $S \beta$-thal), and other combinations of haemoglobin $S$ and other abnormal haemoglobins.

Haematologists were approached, rather than physicians or paediatricians, since haematologists were more likely to know all the patients with sickle-cell disease seen at their hospitals.

\section{Results}

Replies were received from 209 of the 227 haematologists (92\%). They represented 193 centres-that is, hospitals or groups of hospitals. A second questionnaire was sent to those doctors who had replied, requesting details of chronic management, the type of complications, and number of deaths.

All NHS regions in England were represented and 81 of the 90 NHS areas in England and six of the eight area health authorities in Wales.

A total of 1367 cases of SCD were recorded. The major concentrations of patients were in Greater London (862) and Birmingham and its environs (102), but appreciable numbers were found elsewhere in the Midlands, in the north, and in the south east. Fifty-five haematologists reported no cases at all. The geographical distribution of cases is shown in the figure. Table I shows the breakdown into the various types of sickle-cell disease. Cases of sickle-cell anaemia (800) accounted for 59\% and $\mathrm{Hb}$ SC disease 30\% (409 cases).

The second questionnaire was designed to give Yes/No answers

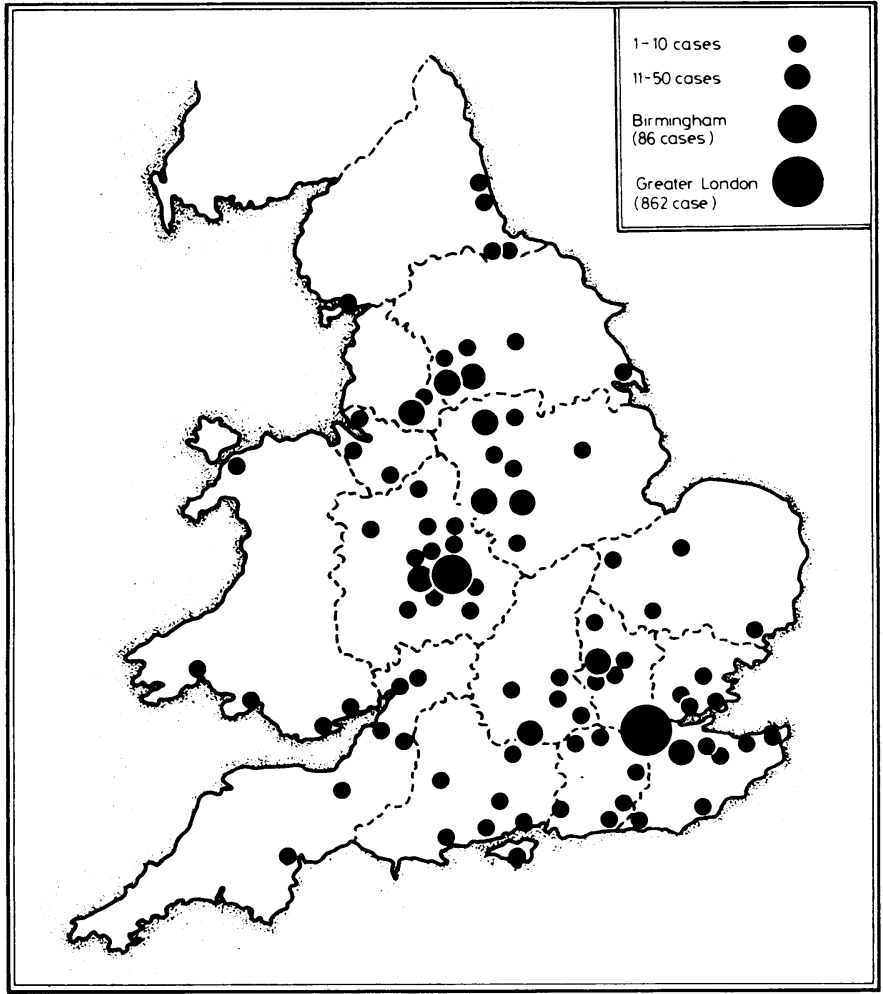

The number of cases of sickle-cell disease in English and Welsh cities and towns from which cases were reported. The NHS regional boundaries are indicated.

TABLE I-Breakdown into the types of sickle-cell disease of 1367 patients

\begin{tabular}{|c|c|c|}
\hline Hb phenotype & \multicolumn{2}{|c|}{ No $(\%)$} \\
\hline $\begin{array}{cl}\text { Haemoglobin } & \text { SS } \\
, & \text { SC } \\
\# & \text { S H } \text {-thalassaemia* } \\
” & \text { SD } \\
, & \text { S and another abnormal haemoglobin }\end{array}$ & $\begin{array}{r}800 \\
409 \\
123 \\
10 \\
9 \\
16\end{array}$ & $\begin{array}{r}(58.5) \\
(29.9) \\
(9.0) \\
(2.6)\end{array}$ \\
\hline
\end{tabular}

*Includes $\beta^{+}$and $\beta^{\circ}$

$+\mathrm{HPFH}=\mathrm{High}$ persistent fetal haemoglobin gene. to specific features of the management, complications, and deaths from sickle-cell disease in order to establish the overall picture in the country without details, and the results must be interpreted with caution. Most patients apparently are the clinical responsibility of haematologists or paediatricians or both, and a smaller number of physicians are concerned. In many cases it was indicated that management is shared jointly, the haematologist sometimes dealing with outpatients and the physician with inpatients. This possibly reflects local arrangements for looking after haematology patients in general.

Replies to the second questionnaire were received from haematologists at 89 of the 193 centres approached, including comments from 19 of the 55 who had not seen any cases of sickle-cell disease during the year covered by the first questionnaire. Replies from the 70 out of 138 centres with patients $(51 \%)$ may be considered representative of the whole as they concerned a similar proportion of the patients $(58 \%)$. Details of management are summarised in table II, in which the centres have been subdivided into those with under 10 patients and those with 10-150 patients. Complications are shown in table III and deaths in table IV.

TABLE II-Information obtained from second questionnaire

\begin{tabular}{|c|c|c|c|}
\hline Size of centre & $\begin{array}{c}10 \\
\text { patients }\end{array}$ & $\begin{array}{c}10-150 \\
\text { patients }\end{array}$ & Total \\
\hline No of replies & 52 & 18 & 70 \\
\hline $\begin{array}{llll}\begin{array}{l}\text { Clinical responsibility } \\
\text { Haematologist }\end{array} & & \\
\text { Paediatrician } & \ldots & \ldots & \ldots \\
\text { Physician } & \ldots & \ldots \\
\text { No (") seeing patients } & \text { regularly } \\
\text { in the steady state } \\
\text { No (")) holding sickle-cell clinics } \\
\text { No }\end{array}$ & $\begin{array}{l}33 \\
33 \\
19 \\
36\left(\begin{array}{c}(69 \cdot 2) \\
1\end{array}(1 \cdot 9)\right.\end{array}$ & $\begin{array}{r}15(83.3) \\
8(44.9)\end{array}$ & $\begin{array}{r}51(72 \cdot 9) \\
9(12 \cdot 9)\end{array}$ \\
\hline $\begin{array}{l}\text { No ("o) using prophylactic agents } \\
\text { Penicillin.. } \\
\text { Folic acid } \\
\text { Polyvalent pneumococcal vaccine }\end{array}$ & $\begin{array}{r}9(17 \cdot 3) \\
39(75 \cdot 0) \\
2(3 \cdot 8)\end{array}$ & $\begin{array}{r}8(44 \cdot 4) \\
17(94 \cdot 4) \\
2(11 \cdot 1)\end{array}$ & $\begin{array}{r}17(24 \cdot 3) \\
56(80 \cdot 0) \\
4(5 \cdot 7)\end{array}$ \\
\hline $\begin{array}{l}\text { No (") screening pregnant women } \\
\text { for haemoglobinopathies } \\
\text { No (") screening neonates for } \\
\text { sickle-cell disease }\end{array}$ & $32(61.5)$ & $15(83 \cdot 3)$ & $\begin{array}{l}47(67 \cdot 1) \\
25(35 \cdot 7)\end{array}$ \\
\hline
\end{tabular}

TABLE III-Complications of sickle-cell disease seen by haematologists in England and Wales. (Number of cases seen at each centre is not known)

\begin{tabular}{|c|c|c|c|}
\hline \multicolumn{4}{|l|}{ Clinical: } \\
\hline \multicolumn{2}{|c|}{ Central nervous system } & . & 21 \\
\hline & .. & $\therefore$ & 21 \\
\hline Leg ulcers .. & .. & . & 20 \\
\hline Cardiac & $\ldots$ & $\therefore$ & 16 \\
\hline Osteomyelitis & $\therefore$ & $\therefore$ & 15 \\
\hline Eye .. . . & & $\therefore$ & 14 \\
\hline Femoral head i & arction & . & 13 \\
\hline Meningitis... & . & $\therefore$ & 12 \\
\hline Hepatic $\quad \ldots$ & . & $\therefore$ & 10 \\
\hline Renal failure & $\because$ & $\ldots$ & 6 \\
\hline Peptic ulcers & $\therefore$ & $\therefore$ & \\
\hline \multicolumn{4}{|c|}{ Haematological crisis: } \\
\hline Aplastic .. & & . & 13 \\
\hline Sequestration & $\because$ & $\therefore$ & 13 \\
\hline Megaloblastic & $\because$ & $\because$ & 5 \\
\hline
\end{tabular}

\section{Discussion}

This survey has established that sickle-cell disease is widely distributed in England and Wales, though high concentrations are found only in a few areas. It must be emphasised that there are two populations who are potentially affected. Firstly, those of West Indian origin, who form a permanent part of the population, and, secondly, those from Africa, including both permanent residents and a number who are in Britain for educational or other purposes for a limited period. This was brought out by the comments of several haematologists who reported rarely seeing a case apart from an occasional patient who was a student at a local college.

Very probably the number of cases identified in England and Wales is underestimated. Two methods were considered 
TABLE IV-Details of terminal illness, necropsy findings, or both

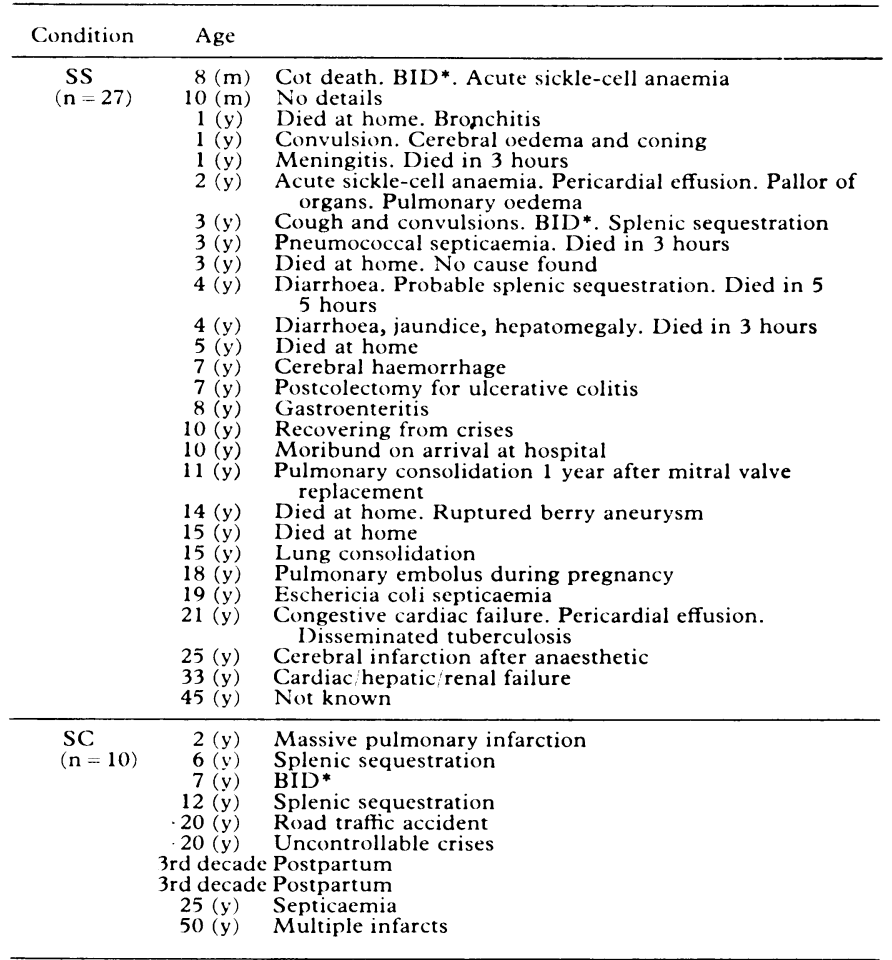

${ }^{*} \mathrm{BID}=$ Brought into hospital dead.

in carrying out the initial survey. Firstly, to ask haematologists for the total number of patients they had seen. This had the obvious disadvantage of an overestimation of numbers due to the same patient being seen in different hospitals; patients having left Britain; and patients who had died. The alternative method was to ask haematologists how many patients had been seen in 1978-9. This had a disadvantage in that it is known that such patients are not regular attenders (especially patients with $\mathrm{Hb} \mathrm{SC}$ disease). Thus the figures returned would not be a true estimation of the numbers of patients. The committee believed, however, that the data would provide a more realistic figure by requesting the number of patients seen within a finite period, and a period of one year was decided on. This would minimise duplication but would underestimate the number of cases. This would be compounded by the absence of information from haematologists who did not reply to the questionnaire or who were not contacted. Either method would exclude the unknown number of undiagnosed cases in the country. Possibly the true number of cases is twice as large.

Thirteen hundred cases of sickle-cell disease, and possibly twice this number, is appreciably greater than the 300 known cases of thalassaemia major in Britain, ${ }^{4}$ but less than the 4000 cases of haemophilia, possibly a similar number of cases of phenylketonuria, and, probably, an even greater number of cases of cystic fibrosis. These other inherited disorders are expensive to treat and, superficially, sickle-cell disease would appear to be much less so. Until more is known of the morbidity of sickle-cell disease in this country, however, this must remain a surmise.

At present, special sickle-cell clinics are run at $13 \%$ of centres, but the principle of seeing the patients regularly is adhered to at a further $60 \%$. Both arrangements are more common where more patients are seen. In several instances it was made clear that the haematologist wishes to see the patients regularly but that patients were not always willing to attend.

A surprising finding was that not all antenatal women of appropriate ethnic groups are examined for haemoglobinopathies (only $67 \%$ of centres) but as replies have been qualified by remarks such as "where appropriate," the situation may be better than it appears. Screening of appropriate neonates for sickle-cell disease is practised less commonly $(36 \%)$. There may be two possible explanations for this. Firstly, it is a relatively new concept and, secondly, reliable results can be obtained only by using a special electrophoretic technique (agar gel) or isoelectric focusing, which is not required for routine diagnostic purposes. Again, both procedures are carried out more often when more patients are seen.

In terms of management prophylactic folic acid is given at $80 \%$ of the centres, but penicillin at only $24 \%$. The occasional cryptic remarks such as "if they take it" shows only that the compliance rate may be low. Polyvalent pneumococcal vaccine is a relatively new form of management, and only four centres reported using it.

If these results represent the views of those in Britain who manage cases of sickle-cell disease, then one may summarise that the majority are in favour of: (1) seeing patients regularly in the steady state (and having a special clinic if the number of cases warrants it); (2) screening pregnant women for haemoglobinopathies (which would thereby establish which infants should be screened); and, (3) giving prophylactic folic acid.

The object of the questions on complications of sickle-cell disease was to discover whether those commonly reported elsewhere were being seen in this country. For this reason the list was not exhaustive, and the number of cases seen by each person was not requested. Painful crises and pulmonary complications were excluded because they were known to be common here. ${ }^{1-3}$ It would appear that all the types of complications listed in table IV have been seen.

Deaths show the features that have been described elsewhere. ${ }^{56}$ Twelve out of 27 deaths from SS occurred at the ages of 5 years or less $(44 \%)$. Eleven out of the $27(40 \%)$ were deaths at home, brought into hospital dead or died within a few hours. The deaths from SC disease were fewer and showed less concentration in the early years. Only one of the 10 was brought into hospital dead.

We thank all the haematologists and other doctors who provided information on their patients, the UK Sickle-Cell Committee on whose behalf the report has been prepared, and Miss Joanne Yates and Mrs Shirley Coupland for clerical help in carrying out the survey and preparing the report.

\section{References}

1 Mann JR. Sickle cell haemoglobinopathies in England. Arch Dis Child $1981 ; 56: 676-83$

${ }^{2}$ Anioniwu E, Walford D, Brozovic M, Kirkwood B. Sickle-cell disease in a British urban community. Br Med f $1981 ; 282: 283-6$.

${ }^{3}$ Murtaza LC, Stroud CE, Davis LR, Cooper DJ. Hospital admissions in children with sickle cell anaemias: A study in South London. $\mathrm{Br} \mathrm{Med} \mathcal{F}$ 1981 ;282:1048-51

Modell B, Ward RHT, Fairweather DVI. Effect of introducing antenatal diagnosis on reproductive behaviour of families at risk for thalassaemia major. Br Med f 1980;280:1347-50.

5 Powars DR. Natural history of sickle cell disease-The first ten years of life. Seminars in Haematology 1975;12:267-85.

6 Seeler RA. Deaths in children with sickle cell anaemia. A clinical analysis of 19 fatal instances in Chicago. Clin Pediatr 1972;11:634-7.

(Accepted 7 August 1981)

\section{Is caudal analgesia suitable for pelvic operations?}

Pelvic operations can be performed under caudal analgesia provided that enough local anaesthetic is given to produce a block up to the tenth thoracic segment. ${ }^{1}$ This may require as much or more drug than when using a lumbar extradural block. With large volumes the risks of toxic manifestations are increased.-JOHN NORMAN, professor of anaesthetics, Southampton.

${ }^{1}$ Atkinson RS, Rushman GB, Lee JA. A synopsis of anaesthesia. 8th ed. Bristol: John Wright and Sons Ltd, 1977:478. 